\title{
AC 2010-1334: ACADEMIC PERFORMANCE AND COOPERATIVE EMPLOYMENT OF TRANSFER SCHOLARS IN ENGINEERING \& ENGINEERING TECHNOLOGY PROGRAMS
}

\section{Surendra Gupta, Rochester Institute of Technology}

"Vinnie" Gupta is a Professor of Mechanical Engineering, and a member of the graduate faculty of Materials Science \& Engineering at the Rochester Institute of Technology (Rochester, NY). He is a recipient of the 2000 Eisenhart Award for Excellence in Teaching. At RIT, he teaches undergraduate and graduate courses in Applied Mechanics, Computational Techniques, and Materials Science.

\section{Daniel Johnson, Rochester Institute of Technology}

Daniel P. Johnson is an Associate Professor and Department Chair in the Manufacturing and Mechanical Engineering Technology/Packaging Science Department at Rochester Institute of Technology. He is the past Program Chair for Manufacturing Engineering Technology and teaches courses in manufacturing operations, automation, robotics, computer aided manufacturing and operations strategy. Prior to joining the MMET/PS Faculty he was Director of RIT's Manufacturing Management and Leadership Program and Engineering Manager for the Center for Integrated Manufacturing Studies. His industrial experience includes work as an Advanced Manufacturing Engineer for Allied Signal. He has a Master of Engineering Degree in Manufacturing and a BS in Industrial and Manufacturing Engineering from RIT as well as an AAS in Engineering Science from Hudson Valley Community College.

John Morelli, Rochester Institute of Technology

John Morelli is a Professor of Environmental Management and Technology and Chair of RIT's Department of Civil Engineering Technology, Environmental Management and Technology. He also holds the endowed Russell C. McCarthy Chair and serves as the Director of RIT's Environmental Management Leadership Initiative. He has directed or co-directed six international symposia in the US and Europe in the areas of environment and sustainability.

\section{Michael Eastman, Rochester Institute of Technology}

Mike Eastman is a Professor and Department Chair of Electrical, Computer, and Telecommunications Engineering Technology at the Rochester Institute of Technology. He teaches courses technical programming and embedded systems design. His research interests include algorithm development and implementation in Field Programmable Gate Arrays.

\section{Vincent Amuso, Rochester Institute of Technology}

Vincent Amuso is an Associate Professor in the Electrical Engineering Department at the Rochester Institute of Technology (Rochester, NY). He has chaired several international conferences in the area of Waveform Diversity \& Design. At RIT, he teaches undergraduate and graduate courses in signal processing and radar and communication systems.

\section{James Moon, Rochester Institute of Technology}

James Moon is an Associate Professor in the Electrical and Microelectronic Engineering department. He was a recipient of the 2009 Eisenhart Award for Excellence in Teaching. At RIT, he teaches undergraduate and graduate courses primarily in semiconductor device physics, solid-state physics, and electronics. 


\section{Academic Performance and Cooperative Employment of Transfer Scholars in Engineering \& Engineering Technology Programs}

\section{Introduction}

Transfer students from two-year schools, both full-time and part-time, are important stakeholders in academic programs at our university, and form an extremely attractive pool to both expand and diversify the engineering and technology workforce of the future. Transfer students are especially important to the five engineering and engineering technology (EET) departments identified in Table 1 that also lists the number of BS degree programs offered in each department.

\begin{tabular}{|l|l|c|}
\hline \multicolumn{2}{|c|}{ Table 1: Participating Academic Departments, Abbreviations, and Programs } \\
\hline Academic Department & Code & $\begin{array}{c}\text { \# of } \\
\text { Programs }\end{array}$ \\
\hline Civil Engineering Technology, Environmental Management \& Safety & CETEMS & 1 \\
\hline Electrical, Computer \& Telecommunications Engineering Technology & ECTET & 3 \\
\hline Manufacturing \& Mechanical Engineering Technology /Packaging Science & MMET/PS & 4 \\
\hline Mechanical Engineering & ME & 1 \\
\hline Electrical and Microelectronics Engineering & EE & 2 \\
\hline
\end{tabular}

All eleven of the BS degree programs in these five departments are ABET-accredited. Our academic calendar is based on four quarters of 11-week duration in a year. All BS degree programs except Packaging Science listed in Table 1 are five-year programs with a mandatory cooperative education component wherein students attend classes in Fall, Winter and Spring quarters in their first two years. In the third, fourth and fifth years, students alternate each quarter between on-campus study and off-campus co-op employment in industry. Thus, each student who enters as a first-term freshman has 12 quarters of on-campus study, and four (or five) quarters of paid co-op employment thus spending a total of five years before graduation. A student transferring from a two-year school at $3^{\text {rd }}$ year-level may spend only six quarters for oncampus study but still needs at least four quarters of co-op employment to graduate with a BS degree. Therefore, a transfer student typically spends a total of three years at the university before graduating.

In AY 2007-8, we submitted a proposal to NSF focusing on students who wish to transfer at the $3^{\text {rd }}$ year level from two-year schools to departments listed in Table 1, and requesting a total scholarship support of $\$ 8,000 /$ student. Our goals were to:

1. Recruit, retain and graduate 75 additional transfer students from our engineering and engineering technology BS programs;

2. Identify women and minority students whenever possible but allow the scholarship to be provided to all students meeting the financial and academic eligibility conditions; 
3. Identify scholars in academic trouble, proactively intervene on their behalf, and arrange help for them to continue and graduate;

4. Prepare scholars with the necessary skills, education, and work experience to enter the high technology workforce upon completion of BS degree; and

5. Perform a regular and thorough assessment of the $\mathrm{ET}^{2}$ program that will be used for the contract reporting purposes and also will be an integral part of our standard program review process.

In August 2008, NSF awarded us a four-year grant from its S-STEM program to support the $\mathrm{ET}^{2}$ Transfer Scholars ${ }^{1}$. In support of this project, the university will contribute $\$ 50,000$ to ensure that continuing $\mathrm{ET}^{2}$ scholars have financial support after the grant expires and help them graduate on time. This support indicates the university's enthusiasm, a firm commitment of service to our EET students, and an endorsement of the goals and objectives of the $\mathrm{ET}^{2}$ program.

For AY 2008-9, the award did not allow us enough time to intensely recruit 5 transfer students in each of the five participating departments for a total of 25 scholars. However, we were able to award scholarships to 22 transfer students who met the financial aid eligibility and U.S. residency criteria. Table 2 lists the distribution of $\mathrm{ET}^{2}$ scholars among the participating departments:

\begin{tabular}{|l|l|c|}
\hline \multicolumn{3}{|c|}{ Table 2: Distribution of AY 2008-9 ET ${ }^{2}$ Scholars } \\
\hline Academic Department & Code & \# of Scholars \\
\hline Mechanical Engineering & ME & 6 \\
\hline Civil Engineering Technology, Environmental Management \& Safety & CET-EMS & 6 \\
\hline Manufacturing \& Mechanical Engineering Technology/Packaging Science & MMET/PS & 8 \\
\hline Electrical and Microelectronics Engineering & EME & 1 \\
\hline Electrical, Computer \& Telecommunications Engineering Technology & ECTET & 1 \\
\hline
\end{tabular}

The one scholar from the EME department took a leave of absence for one year for personal reasons, and came back to the university in Fall'2009. This paper compares the academic performance of the 20 scholars in the first three departments listed in Table 2 relative to their peers, and their placement in cooperative employment positions during their first year at our university.

\section{Department of Mechanical Engineering}

Table 3 provides data about the $\mathrm{ET}^{2}$ scholars and their $3^{\text {rd }}$ year cohorts in the department of mechanical engineering during AY 2008-9. Please note that the Summer numbers appear significantly smaller than those for the rest of the year because the status of $3^{\text {rd }}$ year students is elevated to $4^{\text {th }}$ year at the end of the spring quarter and thus they are not counted in this $3^{\text {rd }}$ year compilation and additionally, $2^{\text {nd }}$ year students are not counted during the summer because they are on vacation during the summer after their second year. 


\begin{tabular}{|c|c|c|c|c|c|}
\hline \multicolumn{6}{|c|}{$\begin{array}{l}\text { Table 3: ME Department Transfer Scholars and Their Cohorts } \\
\text { Program Codes: EMEM, EMEA, EMEV, EMEE,EMED }\end{array}$} \\
\hline Cohort & Quarter $\Rightarrow$ & $\begin{array}{c}\text { Fall } \\
20081\end{array}$ & $\begin{array}{l}\text { Winter } \\
20082\end{array}$ & $\begin{array}{l}\text { Spring } \\
20083\end{array}$ & $\begin{array}{c}\text { Summer } \\
\mathbf{2 0 0 8 4}\end{array}$ \\
\hline \multirow{3}{*}{$\begin{array}{l}\text { ET }^{2} \\
\text { Scholars }\end{array}$} & \# in School & 6 & 6 & 2 & 1 \\
\hline & Mean QGPA & 3.29 & 1.93 & 2.84 & 3.5 \\
\hline & \# on Coop & 0 & 0 & 4 & 5 \\
\hline \multirow{3}{*}{$\begin{array}{l}\text { All } \\
\mathbf{3}^{\text {rd }} \text { Year } \\
\text { Students }\end{array}$} & \# in School & 87 & 79 & 93 & 18 \\
\hline & Mean QGPA & 2.90 & 2.91 & 2.90 & 2.76 \\
\hline & \# on Coop & 26 & 11 & 6 & 18 \\
\hline
\end{tabular}

Of the $\mathrm{ET}^{2}$ six scholars in the department, three were placed on probation due to poor academic performance after the Winter quarter. Two of these three scholars improved their academic performance in the Spring quarter, and in fact, one scholar went on the Dean's List after the Summer quarter. Of the remaining three scholars, two were named to the Dean's List. Table 3 shows that except for the Winter quarter, the current group of $\mathrm{ET}^{2}$ scholars in the department has comparable or better performance than its peer group of students during AY 2008-9.

Four and five $\mathrm{ET}^{2}$ scholars completed required cooperative education assignments during the Spring and Summer quarters respectively. Employers included RIT Mechanical Engineering Department, Advance Testing, Retrotech, Precise Tool \& Manufacturing, and Marquardt Switches. Coop assignments ranged from creating AutoCAD drawing of parts and assemblies to research and development activities in areas of fuel cells and switches.

\section{Department of Civil Engineering Technology (CETEMS)}

Table 4 provides data about the $\mathrm{ET}^{2}$ scholars and their $3^{\text {rd }}$ year cohorts in the department of civil engineering technology during AY 2008-9. Please note that the Summer numbers appear significantly smaller than those for the rest of the year because the status of $3^{\text {rd }}$ year students is elevated to $4^{\text {th }}$ year at the end of the spring quarter and thus they are not counted in this $3^{\text {rd }}$ year compilation and additionally, $2^{\text {nd }}$ year students are not counted during the summer because they are on vacation during the summer after their second year.

\begin{tabular}{|c|c|c|c|c|c|}
\hline \multicolumn{6}{|c|}{$\begin{array}{l}\text { Table 4: CET-EMS Department Transfer Scholars and Their Cohorts } \\
\text { Program Codes: ITFC, IEME, IEMS }\end{array}$} \\
\hline Cohort & Quarter $\Rightarrow$ & $\begin{array}{c}\text { Fall } \\
20081\end{array}$ & $\begin{array}{l}\text { Winter } \\
20082\end{array}$ & $\begin{array}{c}\text { Spring } \\
20083\end{array}$ & $\begin{array}{c}\text { Summer } \\
20084\end{array}$ \\
\hline \multirow{3}{*}{$\begin{array}{l}\text { ET }^{2} \\
\text { Scholars }\end{array}$} & \# in School & 6 & 6 & 1 & 0 \\
\hline & Mean QGPA & 3.13 & 3.06 & 3.25 & NA \\
\hline & \# on Coop & 0 & 0 & 5 & 6 \\
\hline \multirow{3}{*}{\begin{tabular}{|l|} 
All \\
$\mathbf{3}^{\text {rd }}$ Year \\
Students
\end{tabular}} & \# in School & 48 & 47 & 34 & 3 \\
\hline & Mean QGPA & 2.98 & 2.76 & 2.95 & 2.64 \\
\hline & \# on Coop & 0 & 0 & 5 & 14 \\
\hline
\end{tabular}


Table 4 shows that the average quarterly grade point averages of the ET $^{2}$ scholars in CETEMS were higher in every quarter in AY 2008-9 than those of their peer group. Half of the CETEMS $\mathrm{ET}^{2}$ scholars made the Dean's list for at least one quarter during AY 2008-9. None were placed on probation or suspended. After summer, one student decided to accept a permanent job offer from his coop employer, and not pursue degree completion at this time.

CETEMS ET ${ }^{2}$ scholars completed 11 quarters of required cooperative education during the 2008/9 academic year. Employers included Jeffords Steel, Atlantic Testing Laboratories, Magde Land Surveying, City of Rochester Water and Lighting, Bernier Car and Associates, Pike Company and Bernier Carr \& Associates PC. Job titles included Water Engineering Intern, Structural Detailer, Field Surveyor, Lab/Field Construction Technician, Civil Engineering Intern, Construction Project Management Assistant, Engineering Intern, and Construction Materials Testing Technician.

\section{Department of Manufacturing \& Mechanical Engineering Technology \& Packaging Science (MMET/PS)}

Table 5 provides data about the $\mathrm{ET}^{2}$ scholars and their $3^{\text {rd }}$ year cohorts in the department of manufacturing and mechanical engineering technology \& packaging science during AY 2008-9. Please note that the Summer numbers appear significantly smaller than those for the rest of the year because the status of $3^{\text {rd }}$ year students is elevated to $4^{\text {th }}$ year at the end of the spring quarter and thus they are not counted in this $3^{\text {rd }}$ year compilation and additionally, $2^{\text {nd }}$ year students are not counted during the summer because they are on vacation during the summer after their second year.

\begin{tabular}{|c|c|c|c|c|c|}
\hline \multicolumn{6}{|c|}{$\begin{array}{l}\text { Table 5: MMET/PS Department Transfer Scholars and Their Cohorts } \\
\text { Program Codes: ITFM, IPKT, ITFF, ITFS, ITFL }\end{array}$} \\
\hline Cohort & Quarter $\Rightarrow$ & $\begin{array}{c}\text { Fall } \\
20081\end{array}$ & $\begin{array}{l}\text { Winter } \\
20082\end{array}$ & $\begin{array}{c}\text { Spring } \\
20083\end{array}$ & $\begin{array}{c}\text { Summer } \\
20084\end{array}$ \\
\hline \multirow{3}{*}{$\begin{array}{l}\mathbf{E T}^{2} \\
\text { Scholars }\end{array}$} & \# in School & 8 & 8 & 4 & 2 \\
\hline & Mean QGPA & 3.41 & 3.35 & 3.29 & 4.00 \\
\hline & \# on Coop & 0 & 0 & 4 & 6 \\
\hline \multirow{3}{*}{$\begin{array}{l}\text { All } \\
3^{\text {rd }} \text { Year } \\
\text { Students }\end{array}$} & \# in School & 131 & 121 & 87 & 9 \\
\hline & Mean QGPA & 2.85 & 2.86 & 3.00 & 2.58 \\
\hline & \# on Coop & 15 & 16 & 25 & 28 \\
\hline
\end{tabular}

Table 5 shows that the current group of $\mathrm{ET}^{2}$ scholars in MMET/PS recorded consistently higher quarterly grade point averages (QGPA) than their peer group of students during AY 2008-9. Also, no $\mathrm{ET}^{2}$ scholars in the department were reported to have been placed on academic probation, suspension or any other form of negative academic action. During this period four $\mathrm{ET}^{2}$ scholars were placed on the Dean's List for their strong academic performance.

Four $\mathrm{ET}^{2}$ scholars completed required cooperative education assignments during AY 2008-9. Employers included the Center for Integrated Manufacturing Studies, Fulton Group, Arch 
Chemicals and H.J. Heinz. Coop assignment job titles included Mechanical Engineer, EngineerCoop, Intern and Packaging Intern. Pay rates ranged from \$12 to \$20 dollars per hour and duties included packaging research, research testing and modeling for alternative fuel projects and boiler system, pump and gear design. Employers rated the student's performance very well with an average overall performance rating of 4.29 on a scale of 1-5.

\section{Concluding Remarks}

1. The data in tables 3 through 5 indicates that the retention statistics of $\mathrm{ET}^{2}$ scholars is excellent.

2. The data also indicates that the academic performance of $\mathrm{ET}^{2}$ scholars is comparable or better than their peer group of students at the university.

3. Review of student reports and employer evaluations of coops indicates that ET $^{2}$ scholars had meaning and relevant technical assignments, and performed well in these assignments.

4. Informal conversations with the $\mathrm{ET}^{2}$ scholars during the quarterly social get-togethers indicate that they have acclimatized well to our academic and living environments.

5. The above four findings are consistent with those reported in a similar program that was supported previously by NSF at our university. ${ }^{2,3}$

6. The lone scholar from ECTET department (see table 1) was on coop at the MIT Lincoln Laboratories for the Spring and Summer quarters.

7. In Fall of 2009, we recruited an additional 22 students in the $\mathrm{ET}^{2}$ program. We are hoping that these scholars will benefit from the peer mentoring opportunities available through the 2008 cohort of scholars.

\section{Acknowledgements}

This work was supported in part by the National Science Foundation under award number \#DUE-0806757. Help from Ms. Deann Pettinelli in administering the financial aid is gratefully acknowledged. Ms. Joan Graham, Director of Institutional Research and Policy Studies provided the data in tables 3-5.

\section{References}

[1] S. K. Gupta, D. P. Johnson, A. Aghayere, M. Eastman and V. Amuso, ET ${ }^{2}$ Program for Transfer Students from Two-Year Colleges, Proceedings of the 2008 ASEE Annual Conference, 9 pages, 2008. PDF

[2] C. A. Richardson, S. K. Gupta, M. L. Valentine, R. A. Merrill and V. J. Amuso, Multi-department Engineering and Engineering Technology Scholars' Program, Proceedings of the 2005 ASEE Annual Conference, 9 pages, 2005. $\underline{\mathrm{PDF}}$ 
[3] C. A. Richardson, Retention in Engineering Technology Programs at Rochester Institute of Technology, Proceedings of the 2006 ASEE Annual Conference, 12 pages, 2006. PDF 